\title{
Basic Leadership Training for Karang Taruna Tunas Kencana Lengau Seprang Village
}

\section{Ella Silvana Ginting, Tya Wildana Hapsari Lubis, Suci Pertiwi}

\author{
Management \\ Universitas Mikroskil, JI. Thamrin No. 112 Medan, Sumatera Utara, Indonesia \\ Email: ella.silvana@mikroskil.ac.id
}

\begin{abstract}
Karang Taruna is a community social organization as a forum and means where young people can work to create social welfare, especially for the community around where they live. In the era of modernization as it is today, the mindset of the younger generation has begun to decrease to participate in community organizations such as Karang Taruna, especially among young genrasi in the countryside and villages where the younger generation is less concerned about community activities in their villages but not with the younger generation in Lengau Seprang village of Tanjung Morawa District. In recent years, the younger generation in Lengau Seprang village actively participated in the Karang Taruna organization named Tunas Kencana. But because of the lack of experience and knowledge of the younger generation in the organization, especially knowledge about the basics of leadership and lack of support from the surrounding environment also affect the activities of the younger generation in the village. For this reason, a training was given on the basis of leadership for the members of Karang Taruna Tunas Kencana lengau Seprang village. With this basic leadership training, it is expected to help the problems faced by the younger generation that will be useful for them in running the Karang Taruna organization so as to improve the welfare of the community in Lengau Seprang village. The result achieved is a positive response from the younger generation, as well as village head Lengau Seprang who hopes that later training activities like this will often be done in their villages. The conclusion with this basic leadership training is to provide knowledge about the basis in leadership and the science of skills in organizing.
\end{abstract}

Keywords: Leadership, Village, Karang Taruna, Young Generation, Community Service.

\section{Introduction}

Leadership in an organization is the process by which a leader influences and sets an example to his followers in an effort to get the organization's goals. Man has never been separated from the life of the organization. Karang Taruna is a community social organization as a forum and means where young people can work to create social welfare, especially for the community around where they live. In the era of modernization as it is today, the mindset of the younger generation has begun to decrease to participate in community organizations such as Karang Taruna, especially among the younger generation in rural and rural areas where these young people are less concerned about community activities in their villages. As a forum for fostering the young generation of Karang Taruna has a duty as stated in the Minister of Social Affairs Regulation No. 23 of 2013 on The Empowerment of Karang Taruna Clause 8 is Karang Taruna has a duty together with the Government, Provincial Government, and Regency / City Government, and the community to organize the development of the younger generation and organize social welfare. Then Clause 9 in carrying out the duties as referred to in Clause 8, Karang Taruna has a function:

a. Prevent the onset of social welfare problems, especially the younger generation;

b. Organizing social welfare includes rehabilitation, social protection, social security, social empowerment and training of every member of society, especially the younger generation;

c. Improving the economy of productive efforts;

d. Foster, strengthen, and maintain the awareness and social responsibility of each member of society, especially the younger generation to play an active role in the implementation of social welfare;

e. Cultivate, strengthen, and maintain local wisdom; and 
f. Maintaining and strengthening the national spirit of Bhineka Tunggal Ika and the establishment of the Unitary State of the Republic of Indonesia.

Leadership in an organization is trust. In order for someone to be a good leader, of course, it will take long years of experience in an organization. But this is no longer a problem with leadership training services and consultation for the development of human resources and organizations. The younger generation is the next generation of the nation's struggle and human resources for national development, for that the younger generation needs to get special attention and the widest opportunity to be able to grow and develop reasonably. In some areas, Karang Taruna organization is quite existing social activities and quite impactful. But when reviewed thoroughly in the corners of the archipelago, Karang Taruna has not been widely appreciated by young people in the community. In this case the Ministry of Social Affairs is an institution that should be quite responsible for this situation. The role of their socialization is less evenly distributed in the archipelago so that the Karang Taruna organization is less desirable by the younger generation. But there are also villages that have a fairly active Taruna Reef, for example, karang Taruna Tunas Kencana in Lengau Seprang Village, Sei Merah, Tanjung Morawa which is quite active in organizing in recent years. But the fact that we obtained that the young people who joined the Karang Taruna Tunas Kencana organization in Lengau Seprang Village still lacked experience and lack of their knowledge of the basis of leadership. Lack of understanding and knowledge of young people in terms of organizing themselves and making work planning and directing themselves in making decisions. In addition, the lack of support from the surrounding environment also affects the activities of the younger generation in the village. This is because the majority of young people and young people in this village still do not have understanding and attitude in good organization. If left unchecked, of course, this will be bad for the sustainability of the Karang Taruna Tunas Kencana organization in Lengau Seprang Village. So it takes basic leadership training to shape their attitude and mentality in organizing. By conducting socialization on Basic Leadership Training for the younger generation, it is expected that the knowledge of the younger generation will be the basis of leadership will increase and the younger generation will become the baton to continue leadership.

\subsection{Purpose of Acvtivities}

The purpose of this activity is to provide training related to the basics of leadership for the younger generation, namely young members of tunas kencana cadet reef in Lengau Seprang Village so that later they have provisions and skills in organizing.

\subsection{Benefits of Acvtivities}

He expected benefits of this training are that young mudi coral members of Tunas Kencana Village Lengau Seprang village are able to transmit their knowledge and skills in organizing to other young generation at least in their villages that affect the improvement of the quality of human resources and increase the productivity of the village community.

\subsection{External Targets of Community Service}

External Targets in this community service activity, namely: younger generation members of Karang Taruna Tunas Kencana have knowledge and understanding of leadership and are able to apply good management in organizing.

\section{Realization of Activities}

\subsection{Types of Activities \& Schedules, as well as Places of Activity}

a. Methods of Implementation of Activities

Basic leadership training for "Karang Taruna Tunas Kencana Lengau Seprang Village" is carried out by lecture methods and discussions with the younger generation of Karang Taruna members. The lecture method is done by providing an explanation of the importance of leadership in organizing, explaining what skills are needed in the organization, and explaining how to apply good management in the organization. In the second method, the discussion is conducted by giving time when there are 
questions or responses from trainees. The process of implementing community service activities was carried out directly in the office hall of the Village Chief Lengau Seprang on Sunday, February 21, 2021. This training is conducted by three lecturers (chairman of service, member 1 and member 2) who bring pre-determined sections and topics. The implementation of this service was attended by 20 representatives of Karang Taruna Tunas Kencana members of Lengau Seprang Village. At the time of the training, participants were given modules, stationery, medical masks, and handsanitizers in accordance with health protocols recommended by the government to prevent the spread of covid19. During the training process, participants are given training modules that are used as training references.

\section{b. Effective Time of Implementation of Activities}

This Community Service Implementation Activity will be held on December 8, 2020 to February 26, 2021 with the following details:

Table 1. Details of The Time and Implementation of Community Service Activities

\begin{tabular}{|c|c|c|c|}
\hline No & Date & Subject Matter & Participants \\
\hline 1. & $\begin{array}{c}08-22 \\
\text { December } 2020\end{array}$ & a. Preparation of devotional material & - \\
\hline 2. & $\begin{array}{c}05 \text { - } 07 \text { January } \\
2021\end{array}$ & a. Preparation of presentation materials and questionnaires & - \\
\hline 3. & 21 February 2021 & $\begin{array}{ll}\text { a. } & \text { Session 1: Pre-test Questionnaire Filling by participants } \\
\text { b. Session 2: Performance of material by Mrs. Suci - brain storming } \\
\text { video playback for participants } \\
\text { c. Session 3: Submission of material by Mrs. Tya } \\
\text { d. Session 4: Submission of material by Mrs. Ella - motivational } \\
\text { e. } \\
\text { e. Seo playback for participants } \\
\text { f. } & \text { Session 6: Pnteractive discussion } \\
\end{array}$ & 20 \\
\hline 4. & $\begin{array}{c}\text { 22-26 Februari } \\
2021\end{array}$ & a. Final report drafting & - \\
\hline
\end{tabular}

\section{c. Place of Activity}

The place of community service is located at: Jalan Lengau Seprang, Sei Merah, Kec. Tanjung Morawa, Deli Serdang, North Sumatra 20518.

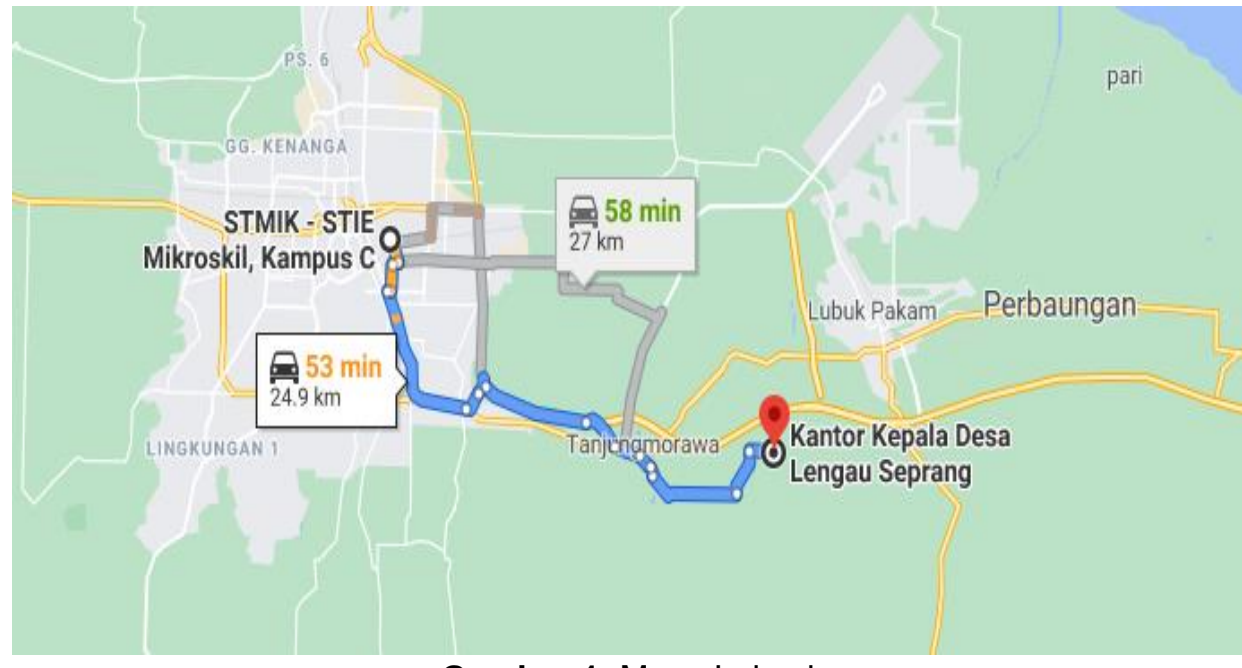

Gambar 1. Maps Lokasi 

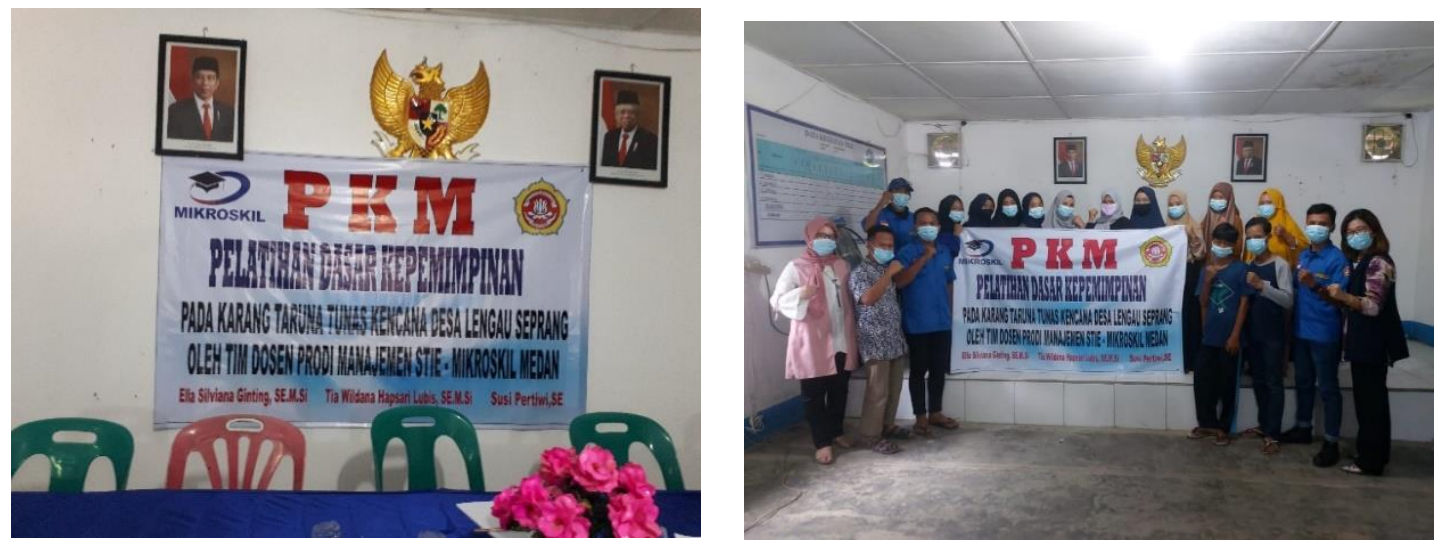

Gambar 2. Tempat Pengabdian

2.2. Members of the Executor of Devotion and Basic Duties and Functions as well (Hours and days)

a. Service Team Arrangement

\begin{tabular}{|l|l|l|l|}
\hline No & \multicolumn{1}{|c|}{ Role in Team } & \multicolumn{1}{|c|}{ Responsibility in the Team } & Lecturer/Student \\
\hline 1 & Ella Silvana Ginting, S.E., M. Si & $\begin{array}{l}\text { Person in Charge and Chairman } \\
\text { of the Service }\end{array}$ & Lecturer \\
\hline 2 & Tya Wildana Hapsari Lubis, S.E., M. Si & Service Members & Lecturer \\
\hline 3 & Suci Pertiwi, S.E & Service Members & Lecturer \\
\hline
\end{tabular}

b. Basic Tasks and Roles of each Service Team

\begin{tabular}{|c|c|c|c|c|}
\hline No & Job Name & Program & Volume (JKEM) & Presenters \\
\hline \multicolumn{5}{|c|}{ Sunday 21 February 2021} \\
\hline 1 & $\begin{array}{l}\text { - Introduction to } \\
\text { Organization } \\
\text { - } \text { Relationships of } \\
\text { Leadership, } \\
\text { Management and } \\
\text { Organization } \\
\text { - Explanation of } \\
\text { Leadership: Goals, } \\
\text { Functions, Types } \\
\text { of Leadership } \\
\text { Styles, } \\
\text { characteristics and } \\
\text { examples of } \\
\text { leadership }\end{array}$ & $\begin{array}{l}\text { - Basic knowledge of the } \\
\text { organization } \\
\text { - Explanation of leadership, } \\
\text { management, and } \\
\text { organizational relationships } \\
\text { - Explaining the understanding } \\
\text { of leadership } \\
\text { - Leadership Function } \\
\text { - Types of Leadership Style } \\
\text { - Characteristics of Leadership } \\
\text { - Examples of Leadership } \\
\text { - Tips to become the Ideal } \\
\text { Leader that employees love }\end{array}$ & $9: 30$ am to $1: 30 \mathrm{pm}$ & $\begin{array}{l}\text { Ella Sivana Ginting, } \\
\text { S.E., M. Si } \\
\text { Tya Wildana Hapsari } \\
\text { Lubis, S.E., M. Si } \\
\text { Suci Pertiwi, S.E }\end{array}$ \\
\hline
\end{tabular}

\subsection{Summary/Outline - Outline of The Material}

a. Young Generation Character Coaching

The development of the younger generation is one of the programs that are being encouraged by the government. Deputy for Youth Resource Improvement of the Ministry of Youth and Sports of the Republic of Indonesia in Samarinda, East Kalimantan in 2013. He in his seminar conveyed the task of youth there are three, namely as agents of change, social control, and future leaders. This can be achieved by youth by following organizations and various youth activities. Youth as one of the elements of the Indonesian people, one of the parts of the nation that has a strategic and potential position. Young intellectuals who grew up with the title of agent of change, social control and iron stock, are awaiting his contribution to help solve the problems that plague the beloved country, Indonesia. 
Indonesia has a promising human resource potential. Youth as one of these resources is needed as one of the development actors in Indonesia because in fact youth is a future leader who will hold the leadership and run the government.

Karang Taruna is one of the community social organizations recognized in the implementation of social welfare as stated in Clause 38 paragraph (2) letter D, Chapter VII on the Role of Society Law No. 11 of 2009 on Social Welfare.

\section{b. Organization}

Organization can be interpreted variously depending on which direction we look at it. Classical theory views organization as a form, while in systems theory it views organization as a process. Organization is a system of roles, flow of activities and processes (patterns of working relationships) and involves several people as executors of tasks designed to achieve common goals. Human life is done in cooperation and in groups, for that indirectly what humans do is organizational behavior. So that the organization is a system of cooperation of a person in interacting. And youth as a generation will indirectly socialize themselves in society. Organization becomes one of the good choices for the means of socialization and youth development.

\section{c. Benefits of Organization}

Organizational benefits include;

a) Fostering a positive mental attitude Organizing makes us aware of the importance of positive mental attitudes. With all the responsibilities in the organization, we are trained to be disciplined, honest, critical thinking, and able to manage time. We are also increasingly trained to make decisions. These attitudes will be achieved in the world of work, making it possible for careers to rise faster.

b) Discuss and Express Opinions

Because in our organization we work with many people whose characters vary, we are required to be able to respect the opinions and listen to the opinions of others. We are also forced to dare to express opinions through discussion, both in meetings and to older parties.

c) Learn Organizational Management

Being active in the organization will teach us to act according to procedures in organizational management. For example, about meeting procedures, how to submit a good proposal, including steps in working on a project.

d) Socializing

In organizing the association will be widespread, we will have many friends from

\section{d. Karang Taruna Organization}

members, younger siblings, seniors, sponsors, and many other important contacts.

Regulation of the minister of social affairs on the basic guidelines of Karang Taruna. Regulation of the minister of social affairs of the Republic of Indonesia Number: 77 / huk / 2010 General provisions containing article one. In this rule, it is referred to by:

a) Karang Taruna is a community social organization as a forum and means of development of every member of society that grows and develops on the basis of awareness and social responsibility of, by and for the community, especially the younger generation in the village / village area, especially engaged in social welfare business.

b) Members of Karang Taruna who are hereinafter called Karang Taruna residents are every member of the community aged 13 (thirteen) years to 45 (forty-five) years who are in the village / village.

c) Forum Of Karang Taruna Management is a container or means of cooperation of Karang Taruna Board, in conducting communication, information, consultation, coordination, consolidation and collaboration, as a social network of Karang Taruna Subdistrict, Regency, Provincial and National Administrators.

Village or called by another name, hereinafter called village is a unitary legal community that has territorial boundaries that are authorized to regulate and take care of the interests of the local community, based on the origins and local customs recognized and respected in the system of Government of the Unitary State of the Republic of Indonesia. 


\section{e. Ideal Leadership Tips.}

a) Be a Good Role Model.

A leader, as you say, is a mirror to your employees. Your actions will determine how they behave. Therefore, as a leader, you must set a good example to employees.

Let's just say, you want to have a team that is disciplined towards time, whether it comes to the office present at a meeting or meeting, and others. Even so with other matters, such as how to dress and talk. The point is, start everything from yourself. Lead yourself before leading others. If you can be consistent with this, then congratulations, you have met one of the ideal leader criteria.

b) Make Yourself a Leader, Not a Boss.

The way to distinguish between a leader and a boss is to see how the team behaves towards you. A leader, when he gives an order, is not just giving orders. More than that, he has humility, is open to discussion, receives criticism and advice for the common good as well as the company.

c) This kind of leader's attitude is usually very favored by subordinates. They will also feel happy and proud to be involved in making decisions. That way, there will be respect from them towards you. Another story with the boss. The word 'boss' is often pinned to superiors who seem the origin of the love of orders. The boss seems indifferent and not open about the task mechanism given, which is important employees must complete the target job, however. In fact, the subordinate also needs guidance when there are difficulties when executing the task. This is why we often hear the term "bossy" whose connotations are negative.

d) Good at Managing Emotions.

Emotions are low, so the energy released is also low. Conversely, if your emotions rise, then the energy channeled is also high. Well, you leaders should be good at controlling the emotions in yourself. Do not let your emotions be at the lowest point, but do not even be emotional because this can backfire on yourself.

e) Hone Your Lead Skills Consistently

As mentioned at the beginning, being an ideal leader requires a process. Every individual has the potential to be a leader. It remains now how the individual, including you, is determined to continue to develop that potential. Being a flexible leader means that you can adapt your leadership style to the situations and conditions that are happening on the ground. This is the best way to develop your leadership skills. Because that way, you know how to behave in various situations.

f) Dare to Admit Mistakes

As human beings, we never escape the name of a mistake. This also applies to a leader. But not a few people who are reluctant to admit their mistakes in the name of sheer prestige. Avoid this if you want to be labeled as a true leader. Instead of looking weak and without integrity, admitting mistakes will make you respected by others.

g) You Can Definitely Be a Great Leader

If all the criteria of an ideal leader are within you, be prepared to be a great leader. Superiors who are not only able to encourage their team to achieve the company's targets, but also liked by colleagues and subordinates. Your good leadership style can be used as an example by other bosses in your company.

\subsection{Target Society}

All young members of tunas kencana cadet coral members lengau Seprang village, the total who participated in this training is as many as 20 members of the coral cadet representatives Tunas Kencana.

\section{Review of Result Achieved}

Devotional activities carried out on young mudi members of tunas kencana cadet coral lengau Seprang village has been going well. This is seen from the interest of trainees to participate in very 
high training activities. This indicates that the trainees welcome the activities that have been carried out. In accordance with the expectations of the chairman and members of the cadet reef, they really expect activities that provide refreshment for young people in this area, either related to deepening knowledge about the organization or related to good management methods in an organization. The Village Head and the village community welcomed the enthusiastic implementation of this activity and hoped that the implementation of activities could be carried out continuously to help improve the quality of the next generation of mudi youth, especially in Lengau Seprang Village. The Principal also hopes that there are further activities that can be given later so that it can improve the quality of the community in the area. In training activities, young mudi coral members tunas kencana cadets are very enthusiastic in participating in training and actively discussing. Thus this devotional activity has been going well.

So it can be concluded that there is an increase in the knowledge and skills of young people in terms of the basics of leadership, how to apply good management in an organization, understand about job descriptions and they are more motivated and understand about the goals and benefits they get from organizing cadet coral activities.

\section{References}

A. Nuryani, E. T. K. Hartuti, R. R. Simangunsong, A. Z. Abidin and J. 2021. Basic Training of Millennial Leadership of Karang Taruna West Pamulang Village. Journal of Community Dharma Service, vol. 1, no. 1.

A. Fathoni. 2009. Organization and Human Resources, Jakarta: Rineka Cipta.

Cahyono. 2017. Karang Taruna Strategy in Fostering Young Generation in Tunggilis Kalipucang Village pangandaran regency. Scientific Journal of Government Science, vol. III, no. 4, pp. 120-131.

D. Sunarsi. 2020. The Anaysis of The Work Environmental and Organizational Cultural Impact on The Performance and Implication of The Work Satidfaction. Scientific Journal of Public Administration Sciences, vol. II, no. 9, pp. 237-246.

Regulation of the Minister of Social Affairs of the Republic of Indonesia. 2009, No. 11 on the Role of Society and Social Welfare, Jakarta: Kemensos.

Regulation of the Minister of Social Affairs of the Republic of Indonesia. 2010, No. 77 on Basic Guidelines for Taruna coral, Jakarta: Kemensos.

Regulation of the Minister of Social Affairs of the Republic of Indonesia. 2013, No. 23 on Empowerment of Karang Taruna, Jakarta: Kemensos.

Sugiyono. 2006. Research Methods (Quantitative, Qualitative and R\&D Approaches). Bandung: CV Alphabet.

S. Torang. 2013. Organization and Management (Behavior, Structure, Culture and Organizational Change), Bandung: Alfabeta.

T. P. Sudaksono and A. Y. Permana. 2016, "Fostering The Leadership Character of the Younger Generation Through The Karang Taruna Organization (Case Study in Kedaton II Village of Batanghari Nuban District of East Lampung Regency). Civic Edu Journal of Civic Education, vol. 1, no. 1.

U. Ahidin, A. Z. Abidin, Y. K. Halomoan, R. J. Permatasari and D. Sunarsi. 2020, Basic Training of Millennial Leadership of West Pamulang Village Cadets, BAKTIMAS Journal of Community Service, vol. II, no. 1. 
66

e-ISSN 2716-1579

5. Attachment

1) Attendee List of Training Participants

Rapat Tangal: 21.02 .2021

HAR, : Mninge

Acaro: Pelatitan Dasar Kepemimpinan Podo karang Toruna Desa Lengau Seprang Tempat: Aula kantor Deso lengau seprang

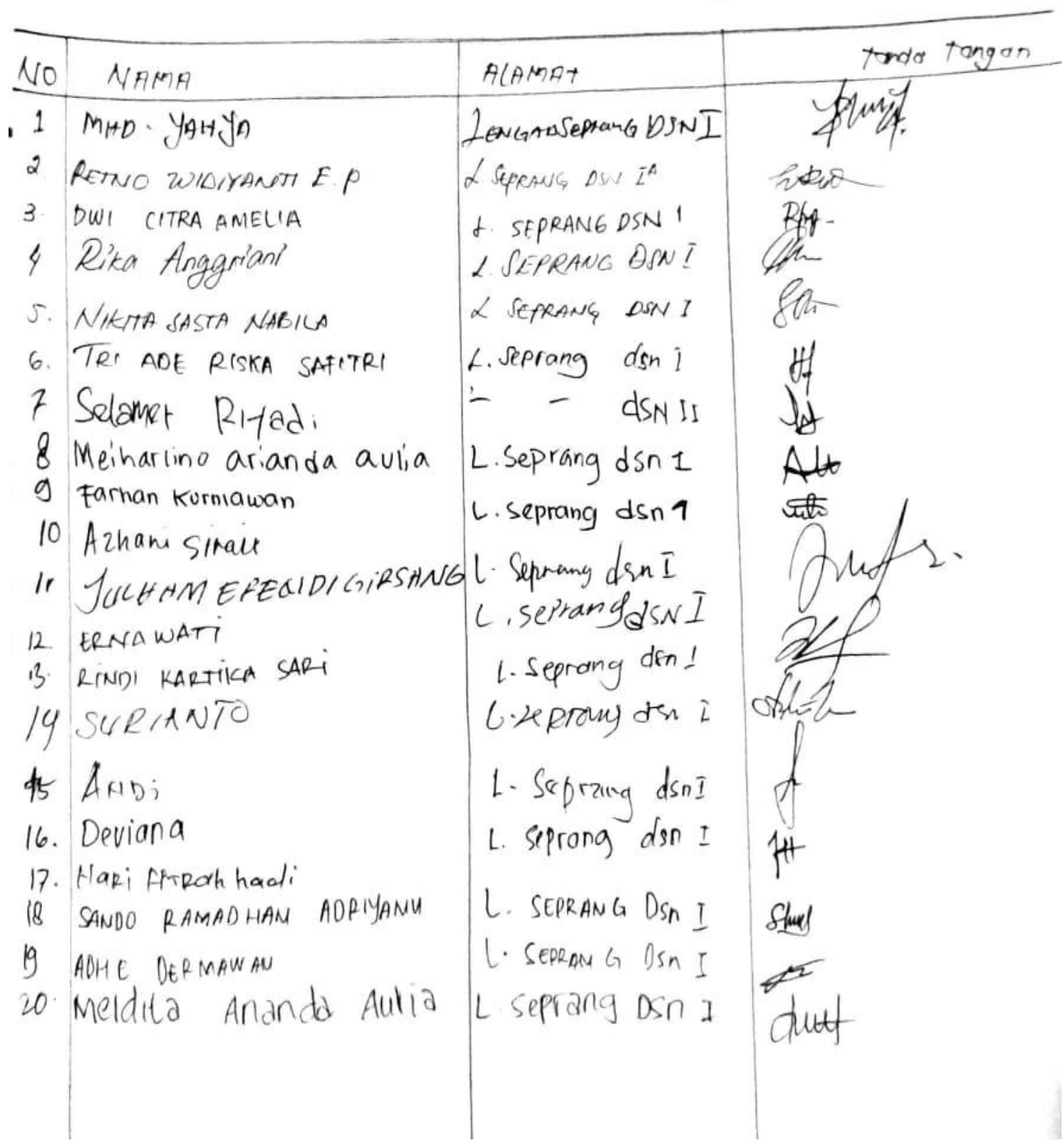

TRIDARMA: Pengabdian Kepada Masyarakat (PkM), Vol.4, No.2 Nopember 2021: 59-69 


\section{2) Partner Cooperation Letter}

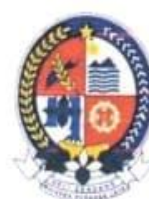

KARANG TARUNA TUNAS KENCANA DESA LENGAU SEPRANG KECAMATANY TANJUNG MORAWA

Alamat : Dusun I Desa Lengau Seprang Kec. Tanjung Morawa Kode Pos : 20362

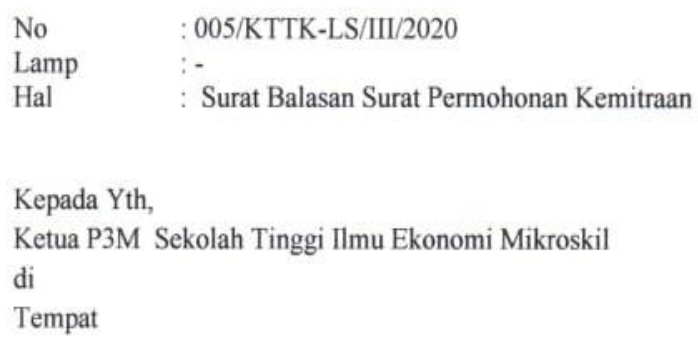

Sehubungan Surat Permohonan Kemitraan Yayasan Bina Pertiwi Medan STIE Mikroskil bernomor 0080 / ST.211/10/PM/2020 19 November 2020, yang diajukan Kepada Kami Karang Taruna Tunas Kencana Desa Lengau Seprang Kecamatan Tanjung Morawa, oleh Dosen STIE Mikroskil untuk Pelaksana kegiatan dan judul kegiatan sebagai berikut :

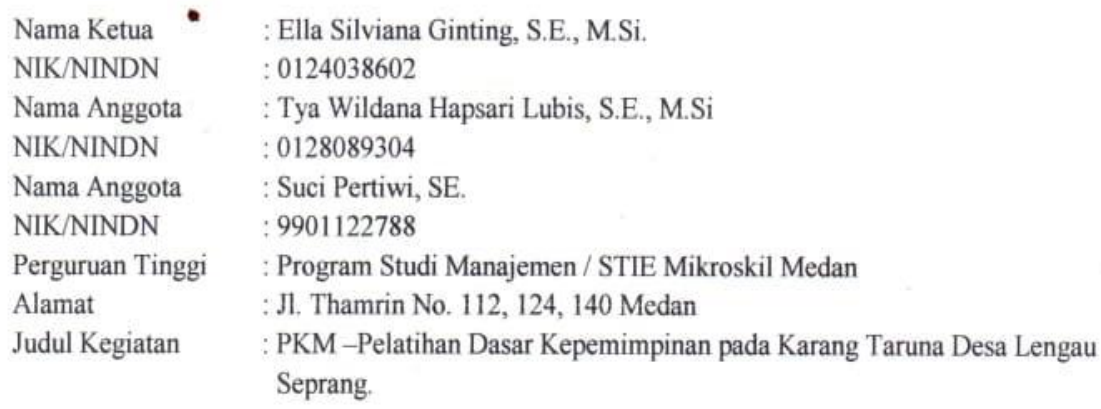

Dengan ini kami bersedia bekerjasama kepada Dosen STIE Mikroskil tersebut di atas untuk melakukan kegiatan Pelatihan Dasar Kepemimpinan pada Karang Taruna Desa Lengau Seprang.

Demikian surat balasan Permohonan Kemitraan dari kami semoga kita bisa menjalin hubungan kemitraan yang baik dalam jangka panjang.

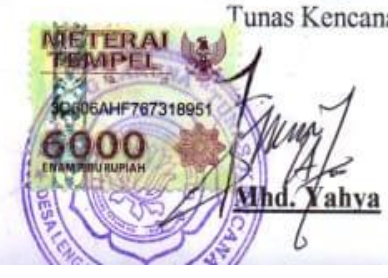




\section{3) Letter of Assignment}

YAYASAN BINA PERTIWI MEDAN

Sekolah Tinggi Ilmu Ekonomi Mikroskil

$\begin{array}{ll}\text { No } & : 0080 / \text { ST } 211 / 10 / P M / 2020 \\ \text { Lampiran } & :- \\ \text { Hal } & \text { : Surat Permohonan Kemitran }\end{array}$

Kepada Yth,

Karang Taruna Desa Lengau Seprang Kecamatan Tanjung Morawa

dis

Tempat

Bersama surat permohonan ini, kami mohon kesediann dari pihak Bapak/Tbu untuk meniadi mitra dalam pelaksanaan kegiatan Pengabdian kepada Masyarakat yang akan dilakukan oleh Dosen STIE Milkroskil. Pelaksana kegiatan dan judul kegiatan adalah sebagai berikut:

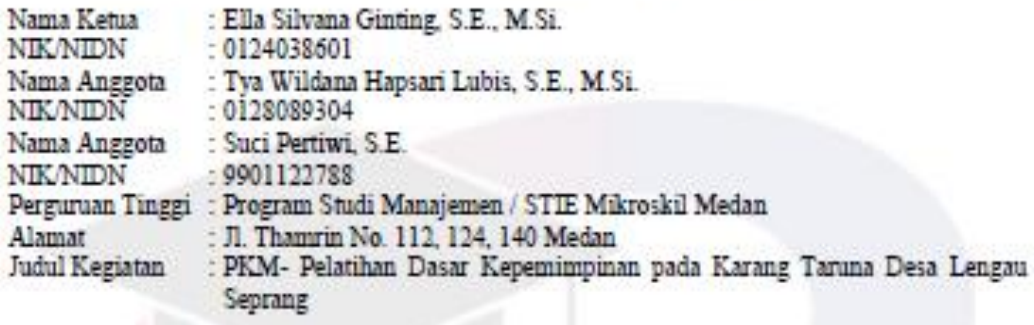

Besar harapan kami kegiatan ini nantinya dapat dilaksanakan dengan baik, sehingga terlaksananva Tridharma Perguruan Tinggi di STIE Miluroskil dan dapat membantu dan meningkatnya pengetahuan tentang Pengembangan dan Pelatihan Dasar Kepemimpinan pada Karang Taruma Desa Lengau Seprang

Demikianlah surat ini kami sampaikan, atas kerjasama yang bavk kami ucapkan banyak terima kasih.

Medan, 19 November 202

Ketua P3M

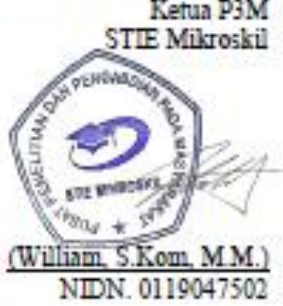

Tembusan

1. Arsip 


\section{4) Documentation}
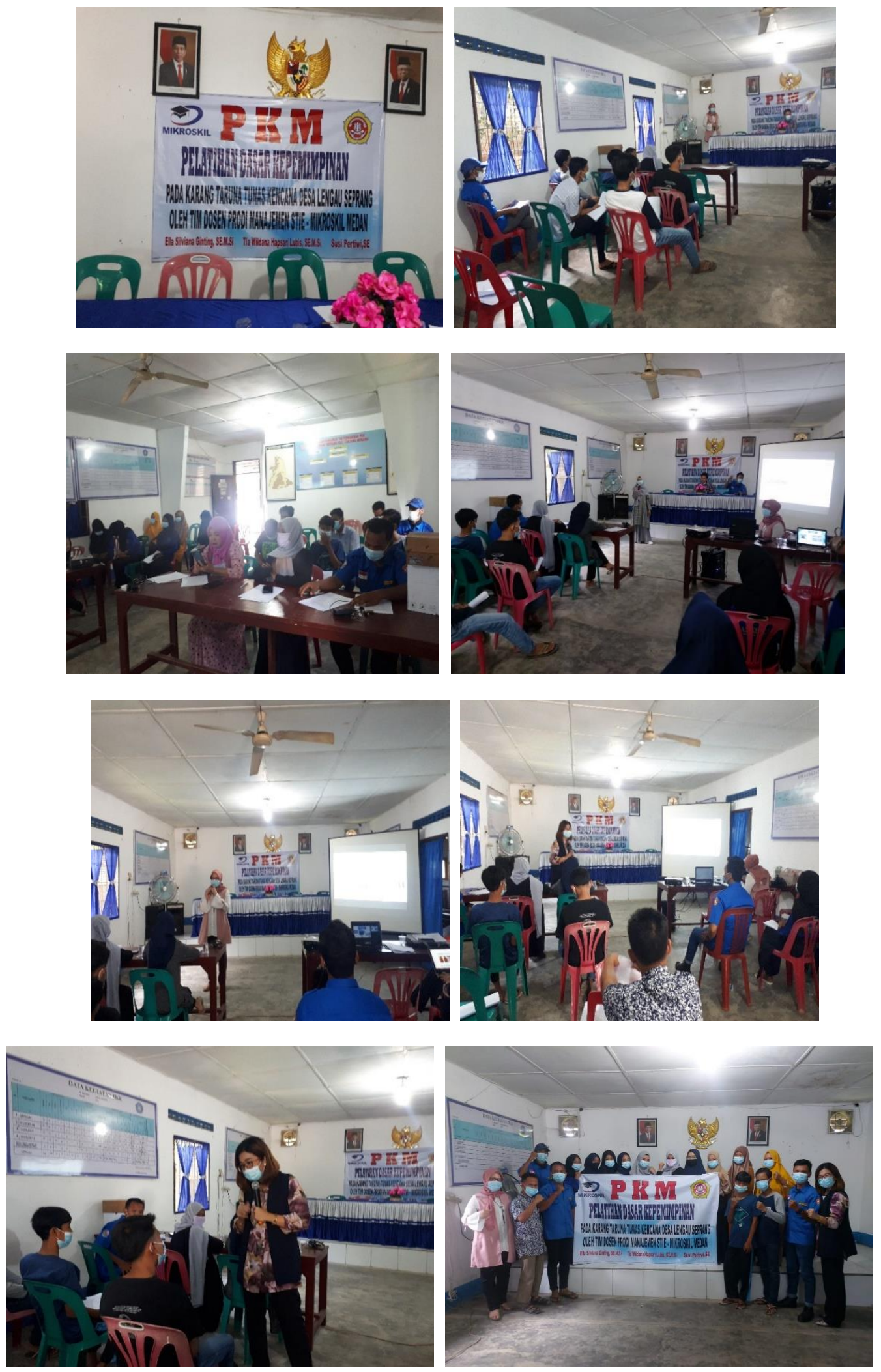

Basic Leadership Training for Karang Taruna Tunas Kencana Lengau Seprang Village (Ella Silvana Ginting at, all) 